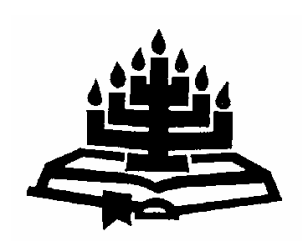

\title{
Vreemdeling in jou eie land? \\ Teologiese riglyne vanuit 1 Petrus, met ' $n$ juridiese begronding
}

\author{
J.J. (Fika) Janse van Rensburg \\ Skool vir Bybelwetenskappe \\ en Bybeltale \\ Potchefstroomkampus \\ Noordwes-Universiteit \\ POTCHEFSTROOM \\ E-pos: sbbjjjvr@puk.ac.za
}

\author{
Gerrit J. Pienaar \\ Fakulteit Regte \\ Potchefstroomkampus \\ Noordwes-Universiteit \\ POTCHEFSTROOM \\ E-pos: pvrgjp@puk.ac.za
}

\begin{abstract}
Stranger in one's own country? Theological guidelines from 1 Peter with a juridical foundation

Some South Africans, more specifically Afrikaans-speaking citizens, experience their present position as that of being foreigners in their own country. Many of the privileges they had enjoyed in the past do not exist anymore. Moreover, it seems as if Afrikaners continuously lose other privileges too. In this article an attempt is made to apply the motif of alienation in 1 Peter to the mentioned situation as well as to highlight relevant stipulations in the South African constitution. The aim with this point of departure is to equip preachers and pastors with a biblically-valid perspective on the problem experienced. Such a perspective can contribute to a more positive attitude among Afrikaner Christians experiencing this kind of alienation and thus urge them to answer to their calling in a spirit of hopefulness.
\end{abstract}

\section{Opsomming}

Vreemdeling in jou eie land? Teologiese riglyne vanuit 1 Petrus, met 'n juridiese begronding

Sommige Suid-Afrikaners, en meer spesifiek Afrikaanssprekende landsburgers, beleef hulle huidige situasie as dié van vreemdelinge in hulle eie land. Talle voorregte wat hulle in die verlede geniet het, bestaan nie meer nie. Meer nog - dit voel vir Afrikaners asof hulle voortdurend ook nog ander voorregte kwytraak. In hierdie artikel word gepoog om die motief van vreemdelingskap in 1 Petrus toe te pas op die genoemde 
probleem, asook om tersaaklike Suid-Afrikaanse grondwetlike bepalings te betrek. Die doel met hierdie vertrekpunt is om predikers en pastors toe te rus om 'n geldige Bybelse perspektief op die probleem te bied. Sodanige perspektief kan moontlik bydra tot 'n meer positiewe houding by AfrikanerChristene wat hierdie belewing van vervreemding het, sodat hulle hulle roeping in Suid-Afrika kan vervul in 'n gees van hoop.

\section{Inleiding}

Die belangrikste probleem wat ondersoek word, is hoe predikers en pastors ontnugterde Christen-Afrikaners met perspektief kan toerus om hulle taak binne die nuwe politieke bedeling in Suid-Afrika te vervul te midde van ontnugtering en 'n gevoel van vervreemding. Dié ondersoek word gedoen deur die motief van vreemdelingskap in 1 Petrus te ontgin. Daarna word nagegaan in watter mate die gevoel van vervreemding werklik gegrond is en vervolgens word die beskerming van die regte van Afrikaners in die huidige konstitusionele bedeling ontleed. Op grond hiervan word ten slotte aangedui hoe Christen-Afrikaners die oproep in 1 Petrus om as "vreemdelinge en bywoners" te leef prakties moet uitleef.

\section{Die motief van vreemdelingskap in 1 Petrus}

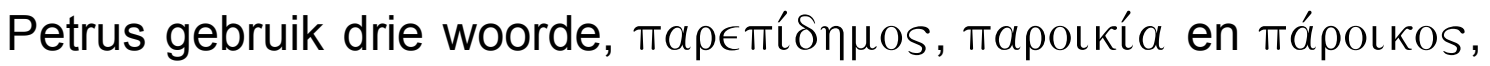
om direk na die motief van vreemdelingskap te verwys, ${ }^{1}$ en 'n verdere twee, $\delta \iota \alpha \sigma \pi о \rho a^{2}$. en B $\alpha \beta \nu \lambda \omega^{\prime} \nu^{3}$, om op 'n indirekte wyse daarna te verwys. 4 Vervolgens word eers 'n oorsig gegee oor die stand van navorsing oor vreemdelingskap in 1 Petrus. Daarna kom

$1 \quad$ By al drie woorde bevat die 1983-Afrikaanse Vertaling die toevoeging "in hierdie wêreld". Hiermee word aan die motief van "vreemdelingskap" in 1 Petrus 'n pertinent kosmologiese kleur gegee - in teenstelling tot 'n sosiale gerigtheid. Die geldigheid van hierdie beklemtoning is te bevraagteken, soos Van Rensburg (1992b) dit beredeneer het.

$2 \Delta$ เ $a \sigma \pi о \rho a ́$ (verstrooiing) dui op die streek of gebied waarbinne persone verstrooi is (spesifiek met verwysing na die volk Israel, wat oor die hele antieke wêreld verstrooi is) (Louw \& Nida, 1988,l:732). Hierdie woord kom slegs in 1 Petrus 1:1

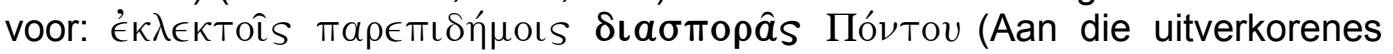
van God, vreemdelinge wat verstrooid woon in die provinsies Pontus ....).

3 B $a \beta u \lambda \omega ́ v$ (Babilon) verwys na Babilon, die hoofstad van Babilonië (Louw \& Nida, 1988, I:834). In 1 Petrus word dié woord slegs in 5:13 gebruik, waarskynlik met

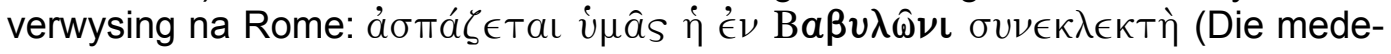
uitverkorene in Babilon stuur vir julle groete).

4 Elliott (1981:39) stel dat hierdie twee woorde by die bestudering van "vreemdelingskap" in 1 Petrus ter sake is. 
die kernbegrippe aan die orde, naamlik 'n betekenisdefinisie 5 van elkeen en dan 'n konstruksie ${ }^{6}$ van uitlanders se status en sosiale posisie in die eerste-eeuse Grieks-Romeinse samelewing.

\subsection{Stand van navorsing oor vreemdelingskap in 1 Petrus ${ }^{7}$}

Verskillende navorsers het primêr of sekondêr belangrike werk gedoen ten opsigte van die vreemdelingskapsmotief in 1 Petrus. Die standpunte kan onder drie hoofde gekategoriseer word:

\section{- 'n Letterlike ${ }^{8}$ (sosiaal-politieke) verstaan van die aard van die vreemdelingskap}

Elliott (1981:48) is byvoorbeeld van mening dat die begrippe

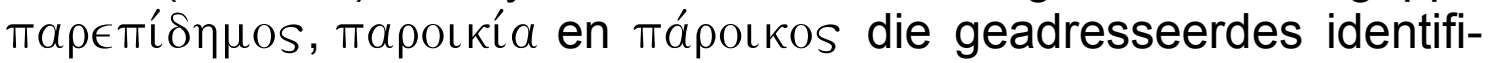
seer as "a combination of displaced persons who are currently aliens permanently residing in (paroikia, paroikoi) or strangers temporarily visiting or passing through (parepidêmoi) the four provinces of Asia Minor". Hy stel verder dat die terme nie alleen die geografiese ontwrigting van die geadresseerdes aandui nie, maar ook hulle politieke, juridiese, sosiale en godsdienstige beperkings en vervreemding wat noodwendig deur geografiese ontwrigting geïmpliseer word.

\section{- 'n Figuurlike en bloot geestelik-godsdienstige ${ }^{9}$ verstaan van die aard van die vreemdelingskap}

Tiperend hiervan is die volgende woorde van Talbert (1986:44) met verwysing na die vreemdelingskapsbegrippe in 1 Petrus 1:1-2, 1:17 en 2:11:

5 Die semantiese model waarvolgens die definisies gemaak word, is die sinchroniese strukturalistiese beskouing van betekenis, soos voorgestel in die Louw-Nida-leksikon (Louw \& Nida, 1988).

6 Die posisie van uitlanders in die eerste-eeuse Grieks-Romeinse samelewing word bepaal volgens die sosio-historiese navorsingsmetode (vgl. Garrett, 1992; Malherbe, 1983). Vergelyk Van Wyk en Van Rensburg (1997:229-240) vir 'n volledige uiteensetting van die destydse posisie van uitlanders.

$7 \quad$ Vergelyk Van Rensburg (1996:39-43) vir 'n volledige bespreking van die stand van navorsing oor vreemdelingskap in 1 Petrus.

8 Benewens Elliott $(1981: 23,48)$ huldig ook Selwyn (1952:144) hierdie standpunt.

9 Benewens Talbert (1986:144) huldig die volgende navorsers ook hierdie standpunt: Malherbe (1983:52-53), Balch (1981:129), Goppelt (1978:176), Furnish (1975:3), Kümmel (1975:418), Wolff (1975:334, 338), Chevallier (1974:395), Beare (1970:135) en Lohse (1954:72, 85). 
This, I think, is figurative language referring to people who, because they are Christians, do not belong to the present age but live as resident aliens in this world. They were outsiders, strangers both socially and religiously.

\section{- 'n Kombinasie van bogenoemde twee interpretasies}

Van Unnik (1980[1942]:73) is oortuig dat die geadresseerdes in 'n dubbele sin van die woord vreemdelinge is. Hulle is "in die wêreld" тápoเкo en in die sinagoge is hulle $\pi \alpha \rho \in \pi i ́ \delta \eta \mu o l$, soos hy uit die verbinding van $\pi \alpha \rho \in \pi i ́ \delta \eta \mu \mathrm{ol}$ aan $\delta \mathrm{\iota} \alpha ́ \sigma \pi \circ \rho \alpha$ in 1:1 aflei. In 'n ander artikel (Van Unnik, 1980:118) sê Van Unnik dat 1 Petrus die volgende visie op die gelowiges het: "The life on earth is compared with that of a colony; the Christians as citizens of the city of God live here as strangers and sojourners."

Die kernbegrippe in verband met genoemde vreemdelingskap kan nou bespreek word.

\section{2 Па́роцкоs (gevestigde uitlander)}

'n Пápoıкоs (gevestigde uitlander) was 'n persoon wat min of meer permanent op 'n plek gewoon het wat nie sy normale tuiste was nie (Van Rensburg, 1992b:300-301). Dié woord kom net een keer in 1 Petrus voor:

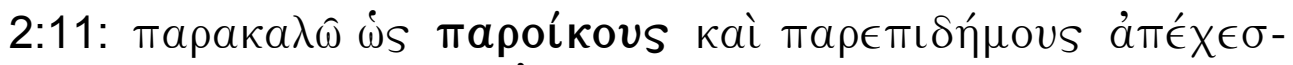

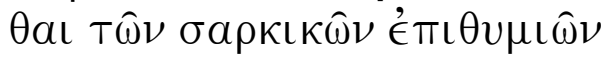

(Julle is 'vreemdelinge' en bywoners. Daarom dring ek by julle daarop aan om nie aan julle natuurlike geaardheid toe te gee nie.)

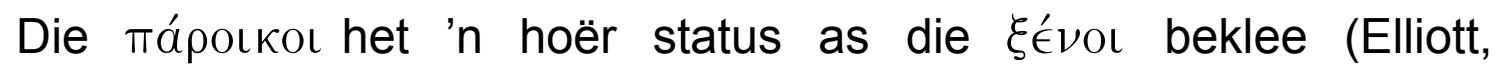
1990:37-38). Schaefer (1949:1695-1707) maak 'n lys van die

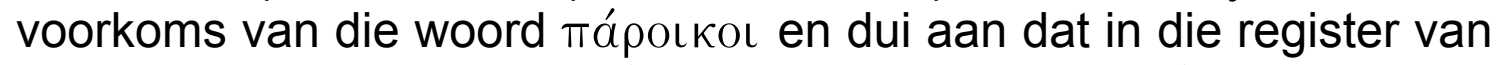
'n stad se inwoners die mápolkol altyd ná die moגítal (burgers) voorkom, maar tog vóór die $\xi$ évol en ook vóór die vrygemaakte persone en die slawe.

Die Griekse woord та́роцкоs (en die Latynse ekwivalent, peregrinus) was die normale woord om die status en klas van uitlanders aan te dui (Elliott, 1990:36; Schmidt \& Schmidt, 1977:842; Berger, 1953:626).

Die status en regte van die tápotкol was noukeurig in die Romeinse reg gestipuleer. Verskeie beperkings was op hulle van 
toepassing. 10 Uitlanders kon mápoıkos-status ontvang as hulle lank genoeg in 'n stad gewoon het. Hierdie status kon ook aan slawe, vrygemaakte slawe of ander persone uit laer klasse gegee word om hulle goedgesindheid of lojaliteit te verseker (Schaefer, 1949:1698; Magie, 1950:149, 225, 1036-1037).

Om as 'n та́роเкоs geklassifiseer te word, het voor- en nadele gehad. Vir die laagste klasse, die haweloses en uitlanders van nieGriekse afkoms, het die verwerwing van mápoเkos-status die deur na sekere politieke en regsvoorregte (Schaefer, 1949:1701) en groter verskuifmoontlikhede na die hoër klasse oopgemaak (Elliott, 1990:25). Hierdie persone het egter uitlanders gebly, sonder die volle regte en voorregte van burgerskap. Hulle was slagoffers van politieke en ekonomiese uitbuiting en het gely onder volgehoue minagting en verdagmakery deur die burgers. Mense uit die laer klasse ( $\xi \in \dot{\epsilon} \nu \mathrm{OL})$ was jaloers op hulle en het met hulle gekompeteer (Elliott, 1990:25-26).

Daar is nie genoeg beskikbare inligting om 'n akkurate bepaling van die hoeveelheid mápoเко in die Hellenistiese tydperk te maak nie (Elliott, 1990:26). Schaefer (1949:1701) voer aan dat daar gedurende die 3de eeu v.C. in Rhodos 1000 mápoเkol vir elke 6000 burgers was en dat daar aanduidings is dat die тápotкоь-getalle baie gegroei het in die daaropvolgende paar eeue.

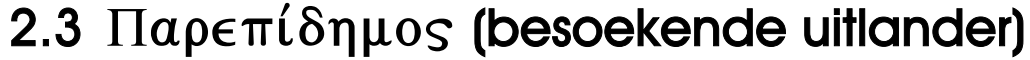

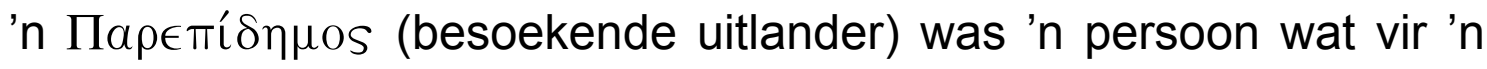
ongedefinieerde tydperk op 'n plek wat nie sy normale tuiste was nie, gewoon het (Van Rensburg, 1992b:300-301; Louw \& Nida, 1988 l:133). Hierdie woord kom twee keer in 1 Petrus voor:

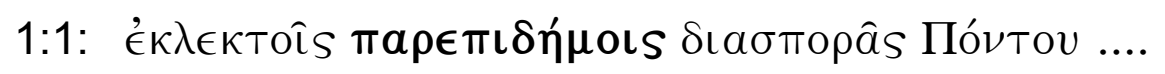

(Aan die uitverkorenes van God, 'vreemdelinge' wat verstrooid woon in die provinsies Pontus ...)

10 Па́роцко het geen politieke regte gehad nie: hulle kon nie aan politieke vergaderings deelneem nie of militêre diens doen nie. 'n Wettige huwelik kon slegs aangegaan word as hulle die ius conubii ontvang het. Ook kon hulle nie 'n testament opstel op dieselfde wyse as wat 'n Romeinse burger dit kon doen nie; hulle kon ook nie in hierdie verband as getuies optree nie. Verder was dit nie moontlik om die erfgenaam van 'n Romeinse burger te wees nie en 'n saketransaksie met 'n Romeinse burger kon slegs aangegaan word as die ius commercii toegeken was. Hulle (тápoı Ко ) kon egter die Romeinse howe besoek en wel aan sekere aktiwiteite deelneem asof hulle Romeinse burgers was (Berger, 1953:626). 


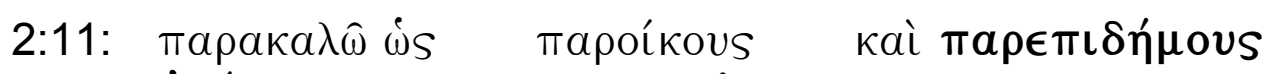

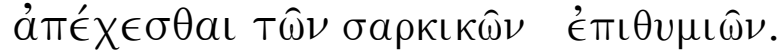

(Julle is vreemdelinge en 'bywoners'. Daarom dring ek by julle daarop aan om nie aan julle natuurlike geaardheid toe te gee nie.)

Die $\pi \alpha \rho \in \pi i ́ \delta \eta \mu$ ol (ook aangedui as $\xi \in$ évol) het 'n laer status as die

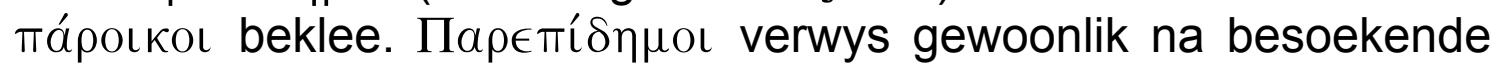
uitlanders (Selwyn, 1952:118; Schmidt \& Schmidt, 1977:842; Bietenhard, 1979b:690).

Die $\pi \alpha \rho \in \pi i ́ \delta \eta \mu$ ol het geen regte gehad nie, behalwe waar 'n $\pi \alpha \rho \in \pi i \delta \eta \mu \mathrm{ol}$ iemand as begunstiger (patroon) gehad het (Bieten-

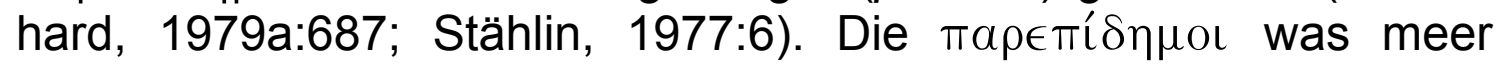
blootgestel aan politieke en ekonomiese uitbuiting, verdagmakery en

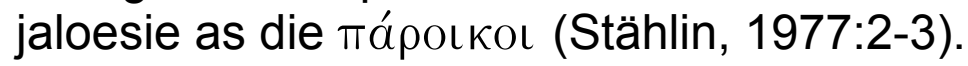

\section{4 Пароı kía (tydperk van vreemdelingskap)}

Пароเкía (tydperk van vreemdelingskap) is 'n ongedefinieerde tydperk of geleentheid waartydens iemand iewers as uitlander woon (in die letterlike sin van die woord), sonder die noodwendige implikasie dat die betrokkene nie fisiese verblyfplek het nie (Van Rensburg, 1992b:301; Louw \& Nida, 1988 I:732). Hierdie woord kom net een keer in 1 Petrus voor:

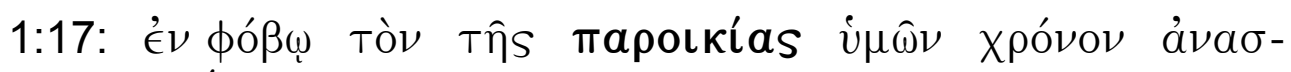
$\tau \rho a ́ \phi \eta T \epsilon$

(... lewe dan in eerbied vir Hom gedurende die tyd van julle 'vreemdelingskap' ...)

\subsection{Gevolgtrekking}

Die eerste lesers/hoorders van 1 Petrus was uitlanders, maar nie bloot in 'n metaforiese, figuurlike sin nie. Hulle was dit ook in 'n letterlike, sosiopolitieke sin van die woord. Hulle het nie eers (geestelike) тароí Kol-status verwerf toe hulle Christene geword het nie, maar was klaar (in die politieke sin van die woord) тароíko voor hulle bekering.

Die skrywer van 1 Petrus beredeneer die feit dat God eintlik die sosiale en politieke тароíkol-status van die geadresseerdes tot sy eer wil gebruik en gee sodoende daaraan 'n dieper dimensie. Hy gee hulle opdrag om vanuit en ten spyte van hulle huidige lae sosiale en politieke status, hierdie "nuwe" status voor God gestand te doen. 
Petrus wil vir hulle 'n nuwe perspektief op hulle situasie gee. Hy doen dit deur hulle te herinner aan spesifieke geloofswaarhede en gedragsvoorskrifte en deur ou waarhede in nuwe omstandighede toe te pas. Hy wil hulle so ver bring om te verstaan dat die blote feit dat God hulle uitverkies het, hulle nie noodwendig vrywaar van die teenstand wat hulle as uitlanders ervaar nie. Hy wil hê hulle moet verstaan dat sulke omstandighede nie as iets ongewoons gesien moet word nie. Hulle moet dié teenstand eerder verwag en besef dat hulle geloof hierdeur op die proef gestel word. Wanneer die gelowiges aanhou goed doen ten spyte van onreg, wys hulle dat hulle slegs Christus as Here in hul lewe erken. Sulke mense sal groot vreugde ervaar met die terugkeer van Christus.

Die Brief is dus ' $n$ aanmoediging vir die lesers om hulleself toe te vertrou aan hulle getroue Skepper en aan te hou goed doen (4:19)

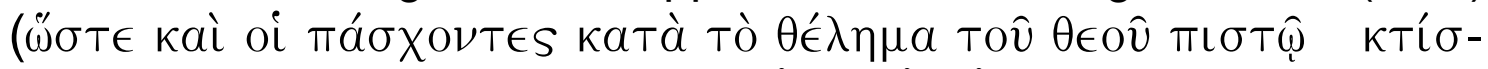

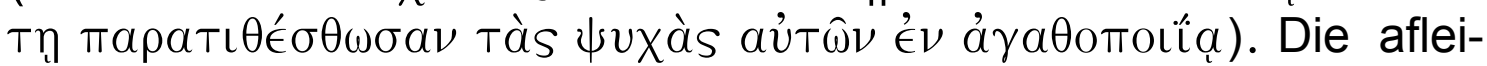
ding dat die Brief die lesers aanmoedig, word duidelik uit die slotvers van die deel wat riglyne gee vir die houding teenoor en die reaksie op diskriminasie $(2: 11-4: 19)$.

Hierdie aanmoediging word alreeds in 2:11-12 aangeraak, waar die skrywer sy basiese opdrag aan "uitlanders" gee:

Geliefdes, julle is vreemdelinge en bywoners. Daarom dring ek by julle daarop aan om nie aan julle natuurlike geaardheid toe te gee nie. Dit verwoes net 'n mens se lewe. Gedra julle altyd goed onder die heidene sodat, al praat hulle kwaad van julle asof julle misdadigers is, hulle julle voorbeeldige lewe kan sien en God kan verheerlik op die dag van afrekening. ${ }^{11}$

In 2:15 word die aanmoediging konkreet gestel:

Dit is die wil van God dat julle deur goed te doen, 'n einde sal maak aan die kwaad wat mense sonder begrip uit onkunde praat. 12

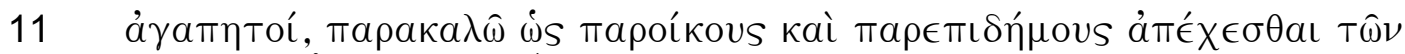

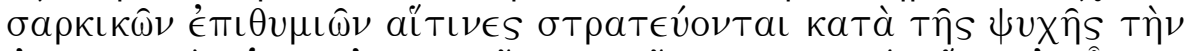

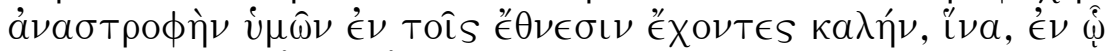

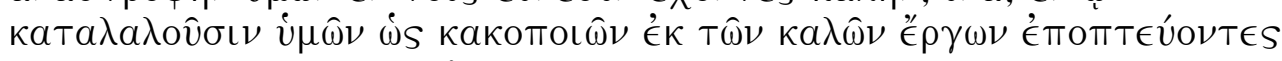

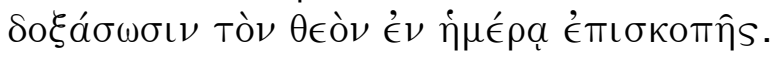

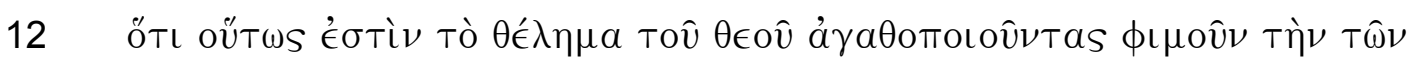

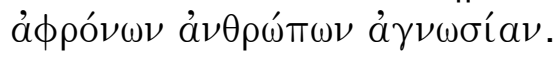


In 3:14-15 word dieselfde tema uitgebrei:

Maar selfs as julle sou ly omdat julle doen wat reg is, moet julle dit as 'n voorreg beskou. Moenie vir mense bang wees of julle laat afskrik nie. In julle harte moet daar heilige eerbied wees net vir Christus die Here. ${ }^{13}$

Petrus se eerste brief gee dus nie 'n teologiese resep om uit die sosiale situasie te ontsnap nie. Die brief lê eerder klem op volgehoue sosiale betrokkenheid. Wanneer gelowiges onder diskriminasie ly, moet hulle sekere dinge doen:

- Hulle moet hulle by uitnemendheid toelê op die uitleef van universele goeie waardes (bv. die onderwerping aan alle menslike owerhede [1 Pet. 2:13-17]; die onderwerping aan hulle werkgewers - ook aan dié wat onredelik is [1 Pet. 2:18-25]; hulle moet goeie huweliksmaats wees [1 Pet. 3:1-7]).

- Hulle moet wys dat Christus die Here van hulle lewe is deur nie toe te gee aan hulle natuurlike geaardheid deur op hulle beurt kwaad te doen nie, maar wel deur aan te hou goed doen (omdat dít is wat die Here wil hê).

Op hierdie manier moet gelowiges nie bloot die Christelike boodskap oordra nie, maar ook 'n ware Christelike leefstyl ontwikkel, onder andere deur sosiale instellings en gedragskodes te ontwikkel. Hierdie instellings en kodes behoort in ooreenstemming met die Bybel te wees en dit moet tegelykertyd hulle gesamentlike identiteit en onderskeibare leefstyl vestig en in stand hou (vgl. Elliott, 1986:77).

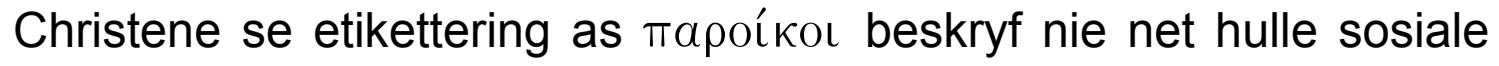
stand nie. In die Brief word hierdie neerhalende etikettering omvorm tot 'n trotse selfaanduiding, deur dit 'n dieper en teologies-positiewe betekenis te gee. Aan die een kant is hierdie etikettering deel van 'n proses om die eretitels van die Ou-Testamentiese volk van God oor te neem. Aan die ander kant word die etikettering omvorm tot ' $n$ trotse selfaanduiding in eie reg.

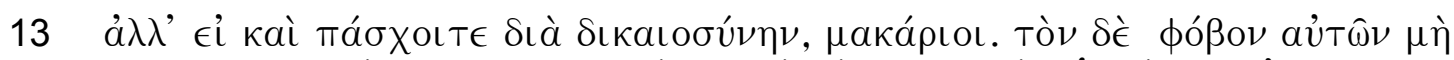

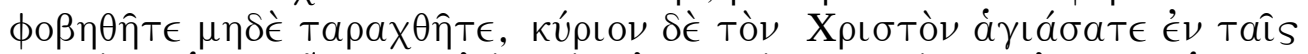

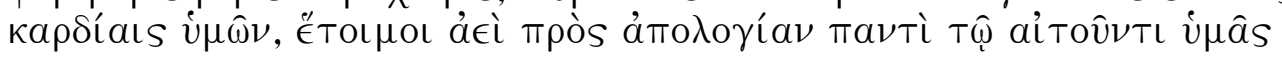

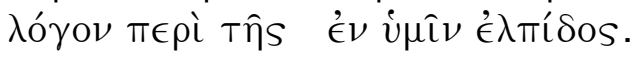




\section{3. 'n Konkretisering van die vreemdelingskapsmotief in 1 Petrus}

Ten einde vas te stel in watter mate die vreemdelingskapsmotief in 1 Petrus van toepassing gemaak kan word op die situasie van huidige Christen-Afrikaners in Suid-Afrika, is dit nodig om eerstens tipiese persepsies van Christen-Afrikaners te ondersoek. Sodoende kan bepaal word of die ontnugtering wat tans beleef word, werklik gegrond is. Tweedens word die konstitusionele beskerming van alle landsburgers ontleed - ook dié van Christen-Afrikaners.

\subsection{Tipiese persepsies van ontnugterde Christen-Afrikaners}

'n Redelik algemene persepsie bestaan onder baie Afrikaners dat dit met hulle in die huidige politieke bedeling veel slegter gaan as wat die toedrag van sake tydens die vorige politieke bedeling was. Dit is algemeen bekend dat die verlede dikwels rooskleuriger as die hede uitsien, aangesien mense maklik onaangenaamhede uit die verlede vergeet, maar voordele beter onthou (die vleispotte-van-Egiptesindroom, of die persepsie van "die goeie ou dae toe alles goedkoper en beter en almal vlytiger en regverdiger was"). ' $n$ Verdere vraag is of die voordele en eksklusiewe owerheidsbeskerming wat Afrikaners in die verlede geniet het, realisties was in terme van opvattings van verantwoordelike meningsvormers wêreldwyd. Dit word dikwels uit die oog verloor dat Afrikaners - veral as gevolg van apartheid, kultuur en ligging - tot en met die negentigerjare uiters geïsoleerd was ten opsigte van die wêreldmening op politieke, ekonomiese, kulturele en opvoedkundige terrein. Voordele wat in ander samelewings onbekend of onvanpas was, is dikwels deur Afrikaners as hul regte beskou.

Een van die groot knelpunte in die hedendaagse Suid-Afrikaanse samelewing is geweld wat ongetwyfeld krisisafmetings aanneem. Maar was die samelewing vantevore geweldloos? Wie kan die stedelike terreur, plaasmoorde en sterftes tydens die bosoorlog, maar veral tydens die Angola-offensief, vergeet? 'n Groot aantal mans, wat destyds jong dienspligtiges was, sowel as vroue en gesinne worstel nou nog om die gevolge van die bosoorlog en hulle deelname daaraan te verwerk. Afrikaners is egter nie die enigste landsburgers wat onder geweld ly nie. Baie fasette van die geweld wat tans publisiteit geniet, is geweld wat swart mense teen swart mense pleeg. Sodanige geweld is net so ernstig as enige ander vorm van geweld. Swart-teen-swart-geweld is in die verlede gerieflikheidshalwe geïgnoreer, maar dit geniet tans baie aandag dikwels onder mense wat nie veel vir die wel en wee van swart 
medeburgers omgee nie. Tog besef sodanige mense wel die publisiteitswaarde daarvan om te beklemtoon hoe sleg dit in SuidAfrika gaan.

'n Baie gewilde onderwerp onder terneergedrukte Afrikaners is die sogenaamde swak ekonomie. Onaanvaarbare hoë vlakke van werkloosheid bestaan wel, maar dit was nog altyd die geval in SuidAfrika, behalwe onder die ekonomies bevoordeelde wittes wat in die verlede deur werkreservering beskerm is. Kan daar enige etiese regverdiging wees vir die werkreservering van die verlede wat op blatante rassediskriminasie berus het? Die onafhanklike politiesekonomiese ontleder, J.P. Landman, toon gesaghebbend aan dat die ekonomiese insinking vroeg in die negentigerjare veroorsaak is deur die isolerende ekonomiese beleid wat sedert 1976 gevolg is (Landman, 2001:10). Wittes in Suid-Afrika was egter verskans teen die gevolge daarvan, deur 'n hoë goudprys en apartheidsmaatreëls - dit het 'n soort veiligheidsnet geskep. Die relatiewe beskerming wat bevoordeeldes in die vorige politieke era geniet het, kon egter nie die fundamentele waarheid verbloem dat alle Suid-Afrikaners tussen die middel van die sewentigerjare en die begin van die negentigerjare in terme van reële inkomste met ongeveer $11 \%$ verarm het nie. Die gevolg hiervan was dat kapitaalbesteding aan infrastruktuur, soos paaie, gesondheid en onderwys, geleidelik verminder het. Hierdie vermindering in kapitaalbesteding het in 'n groot mate bygedra tot die huidige krisisse in die vervoer-, onderwys- en gesondheidsektore. Volgens Landman het hierdie daling gestabiliseer en kan die reële inkomste van alle SuidAfrikaners teen 2010 met ongeveer $17 \%$ styg. Volgens sy vooruitskattings sal hierdie situasie moontlik wees indien 'n gemiddelde ekonomiese groeikoers van $2,5 \%$ en 'n bevolkingsaanwas van $0,9 \%$ gehandhaaf word. ${ }^{14}$ Ekonomiese voordele begin reeds sigbaar word in die sterker Rand, die toename in toerisme (Lascarus, 2004:44-45; Ueckermann, 2004:5)15 en die volhoubare groeikoers die afgelope paar jaar (Van Tonder, 2004:3). Afrikaners deel ook voluit in hierdie voordele.

Pessimiste kla verder oor die onderwys. 'n Aantal rasse-insidente wat al plaasgevind het (byvoorbeeld te Vryburg en Groblersdal)

14 Volgens die Aktuariële Vereniging van Suid-Afrika behoort die bevolkingsaanwas tot $0 \%$ te daal teen 2010 , met 'n gemiddeld van $0,9 \%$ jaarliks tot 2010 . Sien ook Mittner (2000:5) en Steyn (2001:8).

15 Die jaarlikse inkomste uit toerisme het gestyg van R20 miljard in 1999 tot R53,9 miljard in 2003. 
word dikwels aangehaal as 'n bewys van die begin van die ondergang van Afrikaanse moedertaalonderrig. Die bohaai by hierdie skole is grootliks aangeblaas deur politieke aktiviste van verskillende groeperings, wat politieke munt uit hierdie voorvalle wou slaan. Tog is dit tans ' $n$ feit dat die meeste Afrikaanse skole groei en onder die leiding van bekwame personeel en bestuursrade onderwys van ongeveer dieselfde gehalte as voorheen in Afrikaans aanbied (Rademeyer, 2000:4; Joubert, 2000:2; Du Toit, 2004:8). Dit verg vanselfsprekend groter finansiële en ander insette van ouers, maar dit is 'n geringe prys om te betaal vir die wegdoen van die vorige onderwysbedeling toe wit leerders subsidiegewys bevoordeel is bo ander groepe (Rademeyer, 2004:4). Wat tersiêre onderwys betref, was die samesmelting van tersiêre inrigtings traumaties. Die afskaffing van die PUK se "van", die $\mathrm{CHO}$, plaas veral 'n persoonlike verantwoordelikheid op die skouers van Christen-akademici van die Potchefstroomkampus van die voormalige Potchefstroomse Universiteit om voort te gaan met die beoefening van Christelike onderrig en navorsing. Die beoefening van Christelike onderrig en navorsing is wel moontlik, deurdat godsdiensvryheid ingevolge klousule 15 van die Grondwet beskerm word (3.2.2.2). In die nuwe tersiêre bedeling na 2002 vervul histories Afrikaanse universiteite 'n onontbeerlike funksie in die noodsaaklike herstrukturering van hoër onderwys. Dit is dus moontlik om Christelike beginsels op 'n veel groter skaal uit te dra as vantevore (Harrison, 2001:4). Die akademiese en kulturele boikot van Suid-Afrikaanse en veral Afrikaanse akademici wat gehaltenavorsing dikwels bykans onmoontlik gemaak het, is iets van die verlede. Die "muishond"behandeling van die verlede het plek gemaak vir hartlike akademiese samewerking met gespreksgenote wêreldwyd. Verder word private onderwys op die grondslag van taal, godsdiens en/of kultuur grondwetlik gewaarborg en word finansiële bystand van staatsweë vir hierdie inrigtings nie uitgesluit nie (Grondwet 1996 art. 29(3)).

Die toekoms van Afrikaans as amptelike onderrig- en handelstaal lê in die hande van Afrikaanssprekendes (Anon., 2000:7; Rautenbach, 2001:13). Afrikaans, tesame met die ander tale, word in die algemeen beskerm ingevolge artikels 29,30 en 31 van die Grondwet. Hierdie aspek word in paragraaf 4.2 vollediger bespreek. Tog is daar by baie Afrikaners ' $n$ ongeërgdheid of ' $n$ futloosheid ten opsigte van die handhawing van hulle taalregte. Hiervoor kan die nuwe politieke bedeling of ander taalgebruikers nie geblameer word nie (Van Zyl Slabbert, 2002:16). Dié probleem het moontlik ontstaan op grond van die owerheidsbeskerming en verskansing van 
Afrikaans tydens die vorige bedeling. Hierdie verskansing het veroorsaak dat positiewe taalhandhawing nooit nodig was nie. 'n Sprekende voorbeeld van die wyse waarop taalregte daadwerklik gehandhaaf kan word, is dié van die Damaras in Namibië. Nadat hulle vertoë tot die Verenigde Nasies gerig het dat Afrikaans as moedertaalonderrig vir hulle beskikbaar gestel moet word, is op grond van die diskriminerende effek van uitsluiting van Afrikaans 'n resolusie aanvaar dat die Damaras wel geregtig is op moedertaalonderrig in Afrikaans (Bigalke, 2000:11). ' $n$ Verdere voorbeeld is die kontrak wat deur Microsoft gesluit is met taalkundiges van die Potchefstroomkampus om die rekenaarprogramme WindowsXP en Office 2003 in Afrikaans te vertaal (Retief, 2004:25-27). Waarom dan die moedeloosheid by Afrikaanssprekendes in Suid-Afrika?

Diskriminasie blyk die grootste probleem te wees as die situasie in 1 Petrus nagegaan word. Die uitlanders aan wie Petrus geskryf het, het diskriminasie ervaar op grond van die feit dat hulle Christene was (1 Pet. 4:14). Watter Christen in Suid-Afrika kan kla dat daar al op grond van die Christelike godsdiens teen hom/haar gediskrimineer is? Dit is betreurenswaardig dat daar onderling tussen Christene in Suid-Afrika baie voorbeelde is van diskriminasie wat voortspruit uit kerkisme. Oor die feit dat die huidige beleid van godsdiensvryheid in Suid-Afrika algehele godsdiensvryheid vir Christene bewerkstellig, bestaan weinig twyfel. Weliswaar word die Christelike godsdiens op amptelike vlak nie meer soos in die verlede bevoordeel nie, maar vryheid van godsdiens, oortuiging en mening word ingevolge artikel 15 van die Grondwet beskerm (sien 3.2.2.2 vir 'n vollediger bespreking).

In skole en opvoedkundige inrigtings moet die godsdienstige oortuigings van nie-Christene gerespekteer word. Dié voorwaarde plaas 'n groter persoonlike verantwoordelikheid op Christen-ouers, -dosente, -onderwysers en -leerders om Christelike waardes te handhaaf en te bevorder. Op sigself is dié voorwaarde nie noodwendig negatief nie, want dit maak 'n appèl op die mondigheid van Christelike lidmate om persoonlik, sonder owerheidsbeskerming, hulle Christenskap uit te leef. Geen enkele kerk of kerkgroep kan beweer dat op grond van godsdienstige oorwegings met die leerstellings, praktyke of aktiwiteite van sodanige kerk of kerkgroep ingemeng is nie. Al uitsondering hierop is arbeidsaangeleenthede.

Ten spyte van bogenoemde feite, is daar by baie Afrikaanssprekendes die gevoel dat hulle soos vreemdelinge in hulle eie land behandel word. Ten einde te bepaal of hierdie opvatting geregverdig 
is, is dit nodig om die grondwetlike beskerming van alle SuidAfrikaners, insluitend Afrikaners, van naderby te bekyk.

\subsection{Die konstitusionele status van Afrikaners in die huidige Suid-Afrika}

Die geadresseerdes van 1 Petrus het as "vreemdelinge en bywoners" min of geen politieke regte gehad nie. Dié toedrag van sake het daartoe bygedra dat baie van hulle onder diskriminasie gely het. In dié brief van Petrus kry die geadresseerdes riglyne vir hulle reaksie op hierdie diskriminasie en verontregting. Hoe hierdie riglyne op Christen-Afrikaners van toepassing is, kan eers vasgestel word nadat bepaal is wat die konstitusionele status van Afrikaners in die huidige Suid-Afrika is.

In 3.1 is aangevoer dat die hede, net soos die verlede, nie probleemvry is nie. Afrikaners het egter in die vorige bedeling ' $n$ geborgenheid of knusheid beleef wat nie vir ander groeperings (met die uitsondering van Engelssprekende wittes), bestaan het nie. 'n Groot deel van die "diskriminasie" wat Afrikaners tans ervaar, is in werklikheid nie diskriminerende optrede nie. Die speelveld is net in 'n groot mate gelykgemaak (Gouws, 2004:11). Baie Afrikaners wat hulle geborgenheid in hulle politieke en ekonomies-bevoorregteposisie gesoek het, ervaar gelyke regte tans as diskriminerend, soos in die onderstaande beredenering aangetoon sal word.

\subsubsection{Persoonlike regte en vryhede}

Verskeie individuele regte en vryhede word in die Handves van Regte (Hoofstuk 2) van die Grondwet van die Republiek van SuidAfrika 108 van 1996 verskans. Elke individu en regspersoon (in sover 'n reg of 'n vryheid op so 'n regspersoon van toepassing is) kan aanspraak maak op onder andere16 die volgende tipes beskerming (Loubser, 2004:12):

- gelykheid (artikel 9);

- menswaardigheid (artikel 10);

- vryheid en sekerheid van persoon (artikel 12);

- privaatheid (artikel 14);

- vryheid van godsdiens, oortuiging en mening (artikel 15);

16 Hierdie is nie 'n volledige lys nie. Slegs die belangrikste regte en vryhede wat op Afrikaanssprekendes van toepassing mag wees, word vermeld. 
- vryheid van uitdrukking (artikel 16);

- vergadering, betoging, linievorming en petisie (artikel 17);

- vryheid van assosiasie (artikel 18);

- politieke oortuiging (artikel 19);

- vryheid van beweging en verblyf (artikel 21); en

- vryheid van bedryf, beroep en professie (artikel 22).

Ook word die volgende fasette van menswees beskerm:

- arbeid (artikel 23);

- omgewing (artikel 24);

- eiendom (artikel 25);

- onderwys (artikel 29);

- taal en kultuur (artikel 30);

- kultuur-, godsdiens- en taalgemeenskappe (artikel 31);

- regverdige administratiewe optrede (artikel 33); en

- toegang tot howe (artikel 34).

Dit moet deurentyd in gedagte gehou word dat nie een van hierdie regte absoluut en onbeperk geld nie (Pienaar, 2002:266-275). Die een mens se regte word deur die ander se soortgelyke of ander regte beperk en ' $n$ afweging van belange vind gedurig plaas om te bepaal wie se regte voorkeur sal geniet (De Waal, Currie \& Erasmus, 2000:132-153). Die reg op eiendom word byvoorbeeld in artikel 25 verskans. Dié reg wat beskerm word, is egter wyer as slegs eiendomsreg en sluit in alle regte in eiendom (bv. die reg op pensioen of die reg van huurarbeiders op die gebruik van 'n grondstuk, onderhewig aan bepaalde voorwaardes). Dit beteken gevolglik dat 'n eienaar nie met sy eiendom kan maak wat hy/sy wil nie, maar dat die reg beperk word in belang van die samelewing (belasting, onteiening teen vergoeding vir die doeleindes van paaie, nuwe dorpsgebiede of die herstel van grondregte, ensovoorts). Ook impliseer hierdie reg ander individue se reg op eiendom (burereg, wat buureienaars se uitoefening van hulle regte beperk, en die regte van huurders en huurarbeiders, wat eienaars se regte beperk, ensovoorts) (De Bruin, 2004:1). Waar fundamentele regte deur die owerheid beperk word, geld die voorskrifte van artikel 36 van die Grondwet, wat onder andere die volgende bepaal: 
36(1) Die regte in die Handves van Regte kan slegs kragtens 'n algemeen geldende regsvoorskrif beperk word in die mate waarin die beperking redelik en regverdigbaar is in ' $n$ oop en demokratiese samelewing gebaseer op menswaardigheid, gelykheid en vryheid, met inagneming van alle tersaaklike faktore, met inbegrip van

(a) die aard van die reg;

(b) die belangrikheid van die doel van die beperking;

(c ) die aard en omvang van die beperking;

(d) die verband tussen die beperking en die doel daarvan; en

(e) 'n minder beperkende wyse om die doel te bereik.

Die "algemeen geldende regsvoorskrif" waarna in artikel 36(1) verwys word, dui op algemene wetgewing, regspraak en administratiewe maatreëls wat op alle landsburgers van toepassing is en nie sekere groepe of mense uitsonder, bevoordeel of benadeel nie. Die regters van die Konstitusionele Hof beslis wanneer so 'n beperkende maatreël toelaatbaar is. Dié beslissing geskied aan die hand van die algemene beginsel dat die beperking redelik en regverdigbaar is in 'n oop en demokratiese samelewing gebaseer op menswaardigheid, gelykheid en vryheid en aan die hand van die riglyne in artikel 36(1)(a) tot (e) (Jordaan, Joubert \& Coetzee 2004:2). 'n Belangrike riglyn word in (e) vervat, naamlik die vraag of daar nie 'n minder beperkende wyse is waarmee dieselfde doel bereik kan word nie. Dat die beslissings van die regters van die Konstitusionele Hof nie volmaak is nie, spreek vanself. Hierdie aspek was egter ook 'n probleem met die uitsprake van regters uit die vorige bedeling, aangesien dit algemeen aanvaar word dat regters selde absoluut objektief kan wees (Corder, 1984:216-241). 'n Belangrike beginsel is egter dat al nege regters 'n uitspraak oor 'n spesifieke beperking moet lewer en dat die uitspraak van die meerderheid deurslaggewend is. Op grond van die uitsprake van die Konstitusionele Hof wat alreeds gelewer is, blyk dit duidelik dat al die regters erns maak daarmee om die beginsels van menswaardigheid, gelykheid en vryheid deurslaggewend te maak, alhoewel daar altyd meningsverskil sal wees oor die spesifieke toepassing van hierdie beginsels (Loubser, 2004:12).

Die gelykheidsbeginsel, soos vervat in artikel 9 van die Grondwet, word beskou as een van die hoekstene van die grondwetlike bedeling. Hierdie beginsel word toegepas om onregverdigbare diskriminasie (en nié regverdigbare onderskeide nie) te voorkom (Pienaar, 2002:266-275). Afsonderlike openbare toiletgeriewe vir 
mans en dames sal byvoorbeeld regverdigbaar wees, maar die reservering van openbare geriewe soos parke, teaters, strande en ontspanningsgeriewe slegs vir wittes word as onregverdigbare diskriminasie beskou. Ingevolge artikel 9(1) is almal gelyk voor die reg - dit sluit die reg op gelyke beskerming en voordele in. Vir baie Afrikaners beteken die wegneem van hulle vorige bevoordeelde regstatus 'n inbreuk op hulle regte, terwyl dit in alle beskaafde lande wêreldwyd ongehoord is dat bepaalde groepe beskerming en voordele geniet ten koste van ander groepe (Gouws, 2004:11). Artikel 9(2) maak voorsiening vir regstellende aksie om die ongelykhede van die verlede uit die weg te ruim (die speelveld gelyk te kry). Hierdie regstellende aksie bepaal dat wetgewende en ander maatreëls getref word om die beskerming of die ontwikkeling van persone of kategorieë persone wat onbillik deur diskriminasie benadeel is, te verseker. Veral op arbeidsterrein word hierdie maatreël as growwe diskriminasie teen Afrikaners ervaar. Tog is dit 'n bekende feit dat Afrikaners sedert die vyftigerjare hulle eie vorm van regstellende aksie toegepas het en dat werknemers somtyds in die staatsdiens aangestel of bevorder is op grond van Afrikanerskap eerder as op grond van meriete. Hierdie praktyk het tot die negentigerjare voortgeduur. Dieselfde optrede wat tans veroorsaak dat sommige Afrikaners hulleself as vreemdelinge in hul eie land ervaar, is vantevore deur sommige Afrikaners toegepas ten opsigte van medelandsburgers van ander ras-, taal- en kultuurgroepe.

Die gelykheidbeginsel en diskriminasieverbod is op sowel die staat (artikel 9(3)) as op privaat individue en regspersone (artikel 9(4)) van toepassing. Niemand - nie staatsowerheid, staatsinstansies, privaat individue of privaat regspersone - mag regstreeks of onregstreeks onbillik teen 'n persoon diskrimineer op grond van ras, geslagtelikheid, geslag, ${ }^{17}$ swangerskap, huwelikstaat, etniese of sosiale herkoms, kleur, seksuele oriëntering, ouderdom, gestremdheid, godsdiens, gewete, oortuiging, kultuur, taal of geboorte nie. Al bogenoemde vorme van diskriminasie is onbillik of onregverdigbaar, tensy daar bewys kan word dat die onderskeid wel billik of regverdigbaar is (artikel 9(5)). 'n Belangrike riglyn in die bepaling van die onbillikheid al dan nie van 'n onderskeid wat tussen mense gemaak word, is die vraag of die optrede binne die openbare of die privaat sfeer val. Woolman (199610.34) skryf die volgende oor die wanopvatting dat privaatregtelike regshandelinge (handelinge tussen regsubjekte onderling) buite die werking van die Grondwet

17 "Geslag" dui op biologiese en fisiese kenmerke, terwyl "geslagtelikheid" op sosiale en kulturele opvattings dui (De Waal et al., 2000:198). 
val. Hierdie siening is gegrond op die feit dat die Grondwet net sogenaamd vertikale beskerming teen owerheidoptrede sou bied en nie horisontale beskerming in die geval van privaatregtelike verhoudings behoort te bied nie:

Coherance dictates that since the state constructs and enforces all law, all law should be measured against constitutional standards. Candour and genuine commitment to personal autonomy require that all inquiries as to the constitutionality of a particular law should not be artificially or arbitrarily suppressed through the application of a state action or verticality doctrine. These two conclusions come with three important and closely related caveats. First, not all action is state action subject to constitutional scrutiny. Second, attacks on common law do not entail the subversion of the common law - only an honest look at its underlying justifications. Thirdly, the distinction between the public sphere and the private sphere does retain meaning for the purposes of constitutional review.

'n Persoon wat 'n verhouding aanknoop of 'n huwelik sluit met 'n ander persoon kan nouliks geblameer word vir onbillike diskriminasie op grond van die keuse wat uitgeoefen word. So ook het elkeen 'n vrye keuse wie na sy/haar woonplek uitgenooi word. 'n Individu wat 'n persoon in diens neem, se diensverhouding met sodanige persoon word egter deur artikel 23 van die Grondwet (arbeidsverhoudinge) sowel as die Wet op Arbeidsverhoudinge 66 van 1995 gereguleer en val as sodanig in die openbare sfeer. Alle staatsoptrede van staatsowerhede en staatsinstansies val binne die openbare sfeer, terwyl die optrede van privaat organisasies soms binne die openbare sfeer en soms in die private sfeer val, afhangende van die omstandighede.

In hierdie artikel word nie verder in die besonder aandag geskenk aan die uitoefening van individuele fundamentele regte soos die volgende nie: die reg op menswaardigheid (artikel 10), vryheid en sekerheid van persoon (artikel 12), privaatheid (artikel 14), burgerskap (artikel 20), arbeidsverhoudinge (artikel 23) en omgewing (artikel 24). So ook word nie in die besonder gelet op die reg op eiendom (artikel 25), behuising (artikel 26), kinders (artikel 28) en die toegang tot inligting (artikel 32) nie. Aangesien die regte van Afrikaners dikwels in groepsverband uitgeoefen en beskerm word deur deelname aan private godsdienstige, taal- en kultuurorganisasies, word die verband tussen die gelykheidsbeginsel en diskriminasieverbod ingevolge artikel 9 en die reg op vryheid van assosiasie, ingevolge artikel 18, vervolgens onder oë geneem. 


\subsubsection{Vryheid van assosiasie}

Artikel 18 van die Grondwet lui: "Elkeen het die reg op vryheid van assosiasie."

Die begrip vryheid van assosiasie kan op twee wyses vertolk word. 18 Enersyds het elkeen die vryheid om te besluit by watter organisasie hy/sy wil aansluit of nie wil aansluit nie. Hierdie vryheid word teen owerheids- en privaatinmenging beskerm. Andersyds het die lede van 'n private organisasie die vryheid om te bepaal met wie, waarom en wanneer hulle wil assosieer. Hierdie vryheid hou verband met die lidmaatskaps- of toelatingsvereistes van private organisasies. Laasgenoemde aspek dui op die feit dat individue en groepe bepaalde verbintenisse kan sluit en handhaaf wat verband hou met hulle religieuse, sosiale, kulturele en politieke oortuigings. Ook dien hierdie aspek as die manifestering van hulle vryheid van geloof, godsdiens, spraak, uitdrukking, kultuur en taal. Hierdie vryheid lei tot 'n vrye samelewing waarin elke individu hom/haar volgens sy/haar eie vrye keuse kan ontwikkel en uitleef (Woolman \& De Waal, 1994:338-340; De Waal, Currie \& Erasmus, 2000:312318). Vanselfsprekend kom die reg van 'n individu om te besluit by watter organisasie(s) hy/sy wil aansluit, dikwels in botsing met 'n organisasie se lidmaatskaps- of toelatingsvereistes, veral indien die toelatingsvereistes neerkom op die uitsluiting van lede op grond van ras, geslag, taal, kultuur, ouderdom of enige van die ander faktore waarna in artikel 9(3) verwys word. Indien sodanige vereistes op onregverdigbare of onbillike diskriminasie, ingevolge artikel 9(4) neerkom, kan 'n organisasie gedwing word om die diskriminerende lidmaatskapsvereiste te laat vaar. 'n Organisasie kan egter, ingevolge artikel 9(5), die onderskeid regverdig en indien dit 'n billike onderskeid is, sal sodanige lidmaatskapsvereiste(s) toegepas mag word. Die vraag of ' $n$ organisasie in die publieke of private sfeer val, is dikwels deurslaggewend om te bepaal of die onderskeid ingevolge artikel 9(5) billik is en of daar van owerheidsweë 'n nietigverklaring van sodanige lidmaatskapsvereiste(s) mag plaasvind.

\subsubsection{Klubs (verenigings)}

- Voorbeeld 1: Die lidmaatskapsvereistes en interne reëlings van 'n tennisklub met 12 lede wat gebruik maak van 'n privaat tennisbaan sal moeilik deur die owerheid beperk kan word, aangesien sodanige tennisklub vanweë sy aard en aktiwiteite

18 Vir 'n volledige bespreking oor hierdie onderwerp, sien Pienaar (1999:123-138). 
binne die private sfeer val waar vryheid van assosiasie beskerm word. Owerheidsinmenging sal in sodanige omstandighede nie as redelik en regverdigbaar in 'n oop en demokratiese samelewing beskou kan word nie. Indien 'n tennisklub egter van munisipale geriewe gebruik maak en lidmaatskapsvereistes op 'n rassegrondslag openlik geadverteer word, kan die owerheid in openbare belang en ter bevordering van 'n oop en demokratiese samelewing gebaseer op menslike waardigheid, gelykheid en vryheid, inmeng in die interne aangeleenthede van so 'n tennisklub. Die klub se konstitusie en/of optrede na buite het dit dus na die openbare sfeer verskuif, wat owerheidsinmenging ingevolge artikel 9(5) en 36(1) veroorloof.

- Voorbeeld 2: 'n Plaaslike sakekamer waar die onderlinge ekonomiese belange van sakemanne gedien en bevorder word, mag moontlik nog op taal- of ekonomiese grondslae lidmaatskapvereistes stel, maar vereistes op grond van ras en geslag is moeiliker regverdigbaar ingevolge artikel 9(5). 'n Sosiale klub van sakemanne wat geen openbare of ekonomiese nadele vir nielede inhou nie, behoort wel onderskeidende lidmaatskapvereistes te kan stel as gevolg van die private aard daarvan.

Vryheid en gelykheid as beginsels, wat in hierdie verband in ag geneem moet word, is op die oog af teenstrydige beginsels. Dit is noodsaaklik dat 'n afweging van belange plaasvind, wat in elke geval afsonderlik oorweeg moet word. So 'n prosedure sal aandui in watter mate die gelykheidsbeginsel met die vryheid van individue (in hierdie geval die vryheid van assosiasie) versoenbaar is (Davis, 1994:196).

Wanneer diskriminerende maatreëls dus getref word deur klubs, wat in die privaat sfeer optree, behoort die volgende riglyne met betrekking tot die toelaatbaarheid van sodanige onderskeide oorweeg te word (Rautenbach, 1995:54-55):

- Kan die onderskeid gemotiveer word in die lig van die klub se doelstellings en werksaamhede?

- Is die onderskeid in stryd met die openbare belang deurdat dit krenkend van aard is en dus nie as redelik en regverdigbaar in 'n oop en demokratiese samelewing bestempel kan word nie?

- Moet die belange van die lede van die klub voorkeur geniet bo die belange van persone wat wil toetree of gekrenk word deur die klub se doelstellings en werksaamhede? 
In die Amerikaanse reg word onderskei tussen die reg op intimate association en expressive association en in albei gevalle kan (indien geregverdig) aanspraak gemaak word op lidmaatskapsvereistes wat diskriminerend van aard mag wees (Davis, 1994:202-203; Woolman \& De Waal, 1994:345-350; Pienaar, 1999:128-129). In die geval van intimate association is onderskeidende lidmaatskapsvereistes toelaatbaar, as gevolg van die feit dat die klub in die privaat sfeer val (bv. beperkte ledetal en doelstellings wat geen openbare aktiwiteite insluit nie). In die geval van expressive association streef die lede bepaalde gemeenskaplike oogmerke na wat verband hou met taal, kultuur en godsdiens. Hierdie bepaalde oogmerke behoort ook in Suid-Afrika moontlik te wees, ingevolge artikel 31 van die Grondwet wat lui:

31(1) Persone wat aan 'n kultuur-, godsdiens-, of taalgemeenskap behoort, mag nie die reg ontsê word om, saam met ander lede van daardie gemeenskap

(a) hul kultuur te geniet, hul godsdiens te beoefen en hul taal te gebruik nie; en

(b) kultuur-, godsdiens- en taalverenigings en ander organe van die burgerlike gemeenskap te vorm, in stand te hou en daarby aan te sluit nie.

\subsubsection{Kerke en godsdienstige organisasies}

Artikel 15 van die Grondwet bepaal:

15(1) Elkeen het die reg op vryheid van gewete, godsdiens, denke, oortuiging en mening.

15(2) Godsdiensbeoefening kan by staats- of staatsondersteunde instellings geskied, mits:

(a) daardie beoefening reëls nakom wat deur die tersaaklike openbare gesag gemaak is;

(b) dit op 'n billike grondslag geskied; en

(c) bywoning daarvan vry en vrywillig is.

In die eerste instansie is artikel 15(1) daarop gemik om individue se reg op vryheid van geloof, oortuiging en meningsuiting te beskerm, maar saamgelees met artikel 31(1) (sien 3.2.2.1) is die owerheid se reg om in die private aangeleenthede van kerke en kerkgroepe in te meng uiters gering. Dit is dus vir kerke moontlik om te diskrimineer op grond van ras (bv. die lidmaatskapsvereistes van die APK) of geslag (bv. uitsluiting van vroue by kerklike ampte in die geval van die GKSA), mits sodanige uitsluiting op godsdienstige gronde berus. Woolman en De Waal (1994:384) stel dit soos volg: 
Cultural and religious associations will generally find themselves in a similarly advantageous position. To the extent that these associations stick to bona fide religious and cultural activities they will be relatively immune to state intervention. If cultural or religious associations can demonstrate that their discriminatory membership policies legitimately help to preserve their communities' religious or cultural life, then the associational right to determine membership should trump the state's interest in equality. And for good reason: the state's interest in equality here is rather weak. The goods provided by such association are less public than those provided by other types of associations - political and economic - which are legitimately subject to far greater state control.

Alhoewel daar ingevolge artikel 15(2) geen bevoordeling van een godsdienstige groepering bo 'n ander is nie, beskou baie Afrikaners dit as 'n nadeel dat die Christelike godsdiens nie meer van owerheidsweë beskerm en bevorder word nie (De Waal, Currie \& Erasmus, 2000:262-280). Dit is egter 'n ope vraag of sodanige beskerming in 'n land soos Suid-Afrika, met talle godsdienstige strominge, wenslik is, indien die godsdienstige onverdraagsaamheid in lande soos Noord-lerland, Israel, Iran en Irak in gedagte gehou word.

\subsubsection{Ekonomiese (professionele, beroeps- of bedryfs-) verenigings}

In die geval van ekonomiese en beroepsverenigings kan lidmaatskapsvereistes wat diskriminerend van aard is, benewens die feit dat dit in stryd is met die gelykheidsbeginsel, vir persone aansienlike vermoënsregtelike nadeel meebring, deurdat so 'n persoon nie tot 'n gekose beroep of professie kan toetree nie. In hierdie verband bepaal artikel 22 van die Grondwet:

22. Elke burger het die reg om vrylik 'n bedryf, beroep of professie te kies. Die beoefening van 'n bedryf, beroep of professie kan deur die reg gereguleer word.

Hierdie artikel van die Grondwet maak dus uitdruklik daarvoor voorsiening dat professionele liggame en rade die toelatingsvereistes en beroepskwalifikasies vir sodanige professie kan stel, mits die toelatingsvereistes nie neerkom op veral rasse- of geslagsdiskriminasie nie (De Waal, Currie \& Erasmus, 2000:346358; Prince v President Cape Law Society 20022 SA $794(\mathrm{KH})$ ). Dit is ook wel moontlik vir verenigings van beroepslui, wat ter wille van sosiale oorwegings byeenkom en wat nie nadelige gevolge vir nielede met betrekking tot toetrede tot 'n professie of bedryf inhou nie, 
om ingevolge hulle reg op vryheid van assosiasie (artikel 18) toelatingsvereistes te stel. Sodanige verenigings sal ingevolge artikel 9(5) van die Grondwet in staat wees om sodanige onderskeide te motiveer, solank die aktiwiteite en lidmaatskapsvereistes binne die privaat sfeer val (sien 3.2.2.1).

\subsubsection{Slotsom}

Die kontras tussen die situasie van die eerste lesers van 1 Petrus en huidige Christen-Afrikaners blyk duidelik uit die voorafgaande. In Suid-Afrika se Handves van Regte word verskeie individuele politieke, godsdienstige, opvoedkundige, ekonomiese en taal- en kultuurregte van Afrikaners beskerm. Hierbenewens word verskeie politieke, godsdienstige, opvoedkundige, ekonomiese en taal- en kultuurregte wat in groepsverband uitgeoefen word, verskans en beskerm. Vreemdelingskap hou verband met die verlies of nieerkenning van hierdie regte. Afrikaners wat hulle dus as vreemdelinge in hulle eie land beskou, ervaar hierdie sentiment, omdat hulle nie bereid is om hierdie regte in die nuwe bedeling aktief uit te oefen en/of op te eis nie (Pienaar, 2000:7). In hierdie verband is dit noodsaaklik dat die burgerlike samelewing (civil society) hierdie regte moet beskerm, opeis en afdwing (Van Zyl Slabbert, 2002:16).

\section{Die implikasie van die oproepe tot die "vreemdelinge en bywoners" in 1 Petrus vir hedendaagse Christen- Afrikaners $^{19}$}

Uit die voorafgaande is dit duidelik dat sommige Afrikaners ' $n$ ongeldige persepsie het dat hulle vreemdelinge in hulle eie land geword het. Daar is wel praktyke en omstandighede wat hulle 'n gevoel van vervreemding kan laat ervaar. Aangesien Afrikaners, anders as die eerste lesers van 1 Petrus, volledig burgers van die land is, is daar ' $n$ konstitusionele weg om enige verontregting aan die kaak te stel en te laat beëindig.

Predikers en pastors moet gelowiges oproep om die konstitusionele weg te gebruik én moet hulle daarin begelei. Hulle moet gelowige Afrikaners daarop wys dat hulle posisie nie naastenby so benard is as dié van die gelowiges in Petrus se tyd nie. As die oproepe wat God deur Petrus gegee het vir daardie verskriklike diskriminerende

19 Die bepaling van die implikasie van die oproepe in 1 Petrus vir hedendaagse Christen-Afrikaners word gedoen ooreenkomstig die riglyne van Coetzee, Floor en De Klerk (1980). 
situasie gegeld het, hoeveel te meer geld dit nie vir hedendaagse konstitusioneel beskermde Afrikaners nie? Daarom moet elke (Afrikaner-)Christen hierdie grondwetlike regte gebruik wanneer hy/sy diskriminasie en 'n gevoel van vervreemding ervaar. Indien hierdie grondwetlike optrede egter faal of as die weg van appèl op grond van die Grondwet nie gevolg kan word nie, is die boodskap van 1 Petrus duidelik. Die opdragte van 1 Petrus aan die mapoíkoı en $\pi \alpha \rho \epsilon \pi \iota \delta \eta ́ n$ o moet naamlik letterlik en prakties uitgevoer word.

Afrikaner-Christene moet dus die volgende doen wanneer diskriminasie ten spyte van grondwetlike optrede teen hulle voortgaan:

- Hulle optrede moet opval in die uitleef van universele goeie waardes, soos uiteengesit in die Grondwet.

- Hulle moet wys dat Christus hulle enigste Here is, deur nie toe te gee aan hulle natuurlike geaardheid om kwaad met kwaad te vergeld nie. Hulle moet eerder aanhou om goed te doen (1 Pet. 4:19).

- Christene se gedragswyse behoort 'n getuienis te wees van die hoop wat in hulle lewe (1 Pet. 3:15). Sodoende sal hulle in staat wees om ten spyte van verontregting en diskriminasie hulle roeping te vervul.

Afrikaner-Christene wat diskriminasie ervaar, moet dus nie bloot die Christelike belydenis nasê nie, maar behoort 'n ware Christelike leefstyl te ontwikkel. Sosiale instellings en gedragskodes wat Bybels gefundeerd is en wat in ooreenstemming met hulle gesamentlike identiteit en onderskeibare leefstyl is, moet gevestig en gehandhaaf word tot voordeel van alle Suid-Afrikaners.

\section{Gevolgtrekking}

In baie opsigte is Christen-Afrikaners se ervaring dat hulle vreemdelinge in hulle eie land is, 'n persepsie wat dikwels nie klop met die werklikheid nie en soms die werklike stand van sake vererger. Die Grondwet waarborg die regte van elke burger van Suid-Afrika, ook dié van Afrikaners. Christen-Afrikaners moet pastoraal begelei word om die vreemdelingskapsmotief in 1 Petrus te verstaan. Hulle moet insig kry in die moeilike politieke en sosiale posisie van die eerste hoorders/lesers van 1 Petrus en ook hoe God wou hê dat hulle ín daardie uiters moeilike sosiale en politieke omstandighede op hulle vervreemding en diskriminasie moes reageer. 
Só sal Christen-Afrikaners insig kry in die relatiwiteit van hulle eie situasie en sal hulle toegerus en bemagtig wees om hulle gewaarwording van ontnugtering op 'n realistiese wyse te oorkom en hulle roeping in die land hoopvol te vervul.

\section{Geraadpleegde bronne}

ANON. 2000. Afrikaner se moedeloosheid amper verby. Beeld: 7, Des. 16.

BALCH, D.L. 1981. Let wives be submissive: The domestic code in 1 Peter. Chicago: Scholars Press.

BEARE, F.W. 1970. The first Epistle of Peter. (3rd rev. ed.) Oxford: Blackwell.

BERGER, A. 1953. Peregrinus. (In Encyclopedic dictionary of Roman law. Philadelphia: The American Philosophical Society. Vol. 64, Part 2:626627.)

BIETENHARD, H. 1979a. Ksenos. (In Brown, C., ed. The new international dictionary of New Testament theology. Exeter: Paternoster. Vol. 1:686690.)

BIGALKE, I. 2000. Afrikaans rol tog te maklik oor Namibiërs se tong. Beeld: 11, Des. 7.

CHEVALLIER, M.-A. 1974. Condition et vocation des Chreätiens en diaspora. Remarques exeägeätiques sur la 1re Epître de Pierre. Recherches de Science Religieuse, 48:387-398.

COETZEE, J.C., FLOOR, L. \& DE KLERK, B.J. 1980. Hermeneuse van die Skrif met die oog op hedendaagse kerklik-etiese vraagstukke. In die Skriflig, 54(1):12-26.

CORDER, H.M. 1984. Judges at work. The role and attitudes of the South African Appellate Judiciary, 1910-1950. Cape Town: Juta.

DAVIS, D. 1994. Equality and equal protection. (In Van Wyk, D.H. et al., eds. Rights and constitutionalism: the new South African legal order. Cape Town: Juta. p.196-211.)

DE BRUIN, P. 2004. Salomo-uitspraak. Hof neem regte van grondeienaars en plakkers in ag. Beeld: 1, Mei 28.

DE WAAL, J., CURRIE, I. \& ERASMUS, G. 2000. The Bill of Rights handbook. (3rd ed.) Cape Town: Juta.

DU TOIT, Z.B. 2004. 'n Plan vir Afrikaanse skole. Rapport: 8, Mei 16.

ELLIOTT, J.H. 1981. A home for the homeless. A sociological exegesis of 1 Peter, its situation and strategy. Philadelphia: Fortress.

ELLIOTT, J.H. 1986. 1 Peter, its situation and strategy: a discussion with David Balch. (In Talbert, Charles H., ed. Perspectives on first Peter. Macon, Georgia: Mercer University Press. p.61-78.)

ELLIOTT, J.H. 1990. A home for the homeless. A social-scientific criticism of 1 Peter, its situation and strategy. Philadelphia: Fortress.

FURNISH, V. 1975. Elect sojourners in Christ: an approach to the theology of First Peter. Perkins Journal, 28:1-11.

GARRETT, S.R. 1992. Sociology of early Christianity. (In The anchor Bible dictionary. New York: Doubleday. 6:89-99.)

GOPPELT, L. 1978. Der erste Petrusbrief. (8. Ed.) Göttingen: Vandenhoeck \& Ruprecht.

GOUWS, A. 2004. Gelykheid 'n uitlewing van waardes. Beeld: 11, April 26. 
GRONDWET VAN DIE REPUBLIEK VAN SUID-AFRIKA

kyk Republiek van Suid-Afrika. Grondwet van die Republiek van SuidAfrika

HARRISON, B. 2001. Universiteite word oorval. Beeld: 4, Jan. 5.

JORDAAN, W., JOUBERT, J.J. \& COETZEE, G. 2004. Grondwet die lig wat skyn vir vryheid. Beeld Spesiale Bylae: 2, April 22.

JOUBERT, J.J. 2000. Al's pluis met matriekuitslae. Rapport: 2, Des. 31.

KÜMMEL, W.G. 1975. Introduction to the New Testament. Translated and edited by H.C. Kee. Nashville: Abingdon.

LANDMAN, J.P. 2001. Verlede afgeskud. Beeld: 10, Maart 13.

LASCARUS, R. 2004. Handelsnaam: Suid-Afrika. Insig: 44-45, April.

LOHSE, E. 1954. Paraënese und Kerygma im 1. Petrusbrief. Zeitschrift für die neutestamentliche Wissenschaft und die Kunde der älteren Kirche, 45:68-89.

LOUBSER, M. 2004. Grondwet is die hoogste gesag - regte en vryhede van die armste tot die rykste word beskerm. Beeld: 12, April 26.

LOUW, J.P. \& NIDA, E.A., eds. 1988. Greek-English lexicon of the New Testament based on semantic domains. Vol. 1, 2. New York: United Bible Societies.

MAGIE, G. 1950. Roman rule in Asia Minor to the end of the third century after Christ. Princeton: Princeton University Press.

MALHERBE, A.J. 1983. Social aspects of early Christianity. (2nd enl. ed.) Philadelphia: Fortress.

MITTNER, M. 2000. Die nuwe groeisyfer is nie gekook nie. Beeld: 5, April 12.

PIENAAR, G.J. 1999. Legal subjectivity and the juristic person. Potchefstroom: PU vir CHO.

PIENAAR, G.J. 2002. The interaction between freedom of association, the free exercise of religion and equality. Nederduitse Gereformeerde Teologiese Tydskrif, 43(1 \& 2):266-275.

RADEMEYER, A. 2000. Uitslae is geloofwaardig, sê Asmal. Beeld: 4, Des. 29.

RADEMEYER, A. 2004. Onderwys-son kom op. Beeld Spesiale Bylae: 4, April 22.

RAUTENBACH, I.M. 1995. General provisions of the South African Bill of Rights. Durban: Butterworths.

RAUTENBACH, J. 2001. 'n Taal wat bruis soos Afrikaans is g'n aan't kwyn. Beeld: 13, Jan. 1.

REPUBLIEK VAN SUID-AFRIKA. 1995. Wet op Arbeidsverhoudinge 66 van 1995. Pretoria: Staatsdrukker.

REPUBLIEK VAN SUID-AFRIKA. 1996. Grondwet van die Republiek van SuidAfrika 108 van 1996. Pretoria: Staatsdrukker.

RETIEF, L. 2004. Afrikaans kom huis toe. Insig: 25-27, Junie.

SCHAEFER, H. 1949. Paroikoi. (In Paulys Realencyclopädie der classischen Altertumswissenschaft. (Neue Bearb.) Sechshunderddreissigster Halbband, letztes Drittel. Band 18(4):1695-1707.)

SCHMIDT, K.L. \& SCHMIDT, M.A. 1967. Paroikos. (In Friedrich, G., ed. Theological dictionary of the New Testament. Grand Rapids: Eerdmans. Vol. 5:841-853.)

SELWYN, E.G. 1952. The First Epistle of St Peter. (2nd ed.) London: Macmillan.

STÄHLIN, G. 1977. Ksenos. (In Friedrich, G., ed. Theological dictionary of the New Testament. Grand Rapids: Eerdmans. Vol. 5:1-36.) 
STEYN, J. 2001. Afrikaner pas aan - reeds skouspelagtige sukses behaal. Beeld: 8, Jan. 16.

TALBERT, Charles H. 1986. Once again: the plan of 1 Peter. (In Talbert, Charles H., ed. Perspectives on First Peter. Macon: Mercer University Press. p. 141-151.)

UECKERMANN, H. 2004. Toerisme kyk na SA mark. Sake-Rapport: 5, Mei 16.

VAN RENSBURG, FIKA J. 1992a. The outline of First Peter - a reconsideration. Ekklesiastikos Pharos, 74(1):26-41.

VAN RENSBURG, F.J.J. 1992b. Vreemdelingskap in 1 Petrus: Voorlopige definiëring van die betekenisse van die betrokke Griekse woorde. (In Barkhuizen, J.H., Stander, H.F. \& Swart, G.J., reds. Hupomnema. Feesbundel opgedra aan prof. J.P. Louw. Departement Grieks, Universiteit van Pretoria: Pretoria. p. 283-306.)

VAN RENSBURG, FIKA J. 1996. 'n Metodologiese verkenning na die verdiskontering van sosiohistoriese gegewens in die bestudering van vreemdelingskap in 1 Petrus. In die Skriflig, 30(1):37-55.

VAN TONDER, J. 2004. SA glimlag breër oor ekonomie. Sake-Rapport: 3, Mei 25.

VAN UNNIK, W.C. 1980. Corpus Hellenisticum Novi Testamenti. (In Barrett, C.K., ed. Sparsa collecta: The collected essays of W.C. van Unnik. Part 2. Leiden: Brill. p.194-214.) (Supplements to Novum Testamentum. Vol. 30.)

VAN WYK, G.J. \& VAN RENSBURG, FIKA J. 1997. Oíḱtal (huisbediendes) in die eerste-eeuse Grieks-Romeinse samelewing. 'n Sosio-historiese konstruksie vir die interpretasie van 1 Petrus 2:18. In die Skriflig, 31(3):229-249.

VAN ZYL SLABBERT, F. 2002. Is Suid-Afrika haalbaar? Insig: 16, Mei.

WET OP ARBEIDSVERHOUDINGE kyk Republiek van Suid-Afrika. Wet op Arbeidsverhoudinge

WOLFF, C. 1975. Christ und Welt im 1. Petrusbrief. Theologische Literaturzeitung, 100:333-342.

WOOLMAN, S. 1996. Application. (In Chaskelson, M. et al., eds. Constitutional law of South Africa. Cape Town: Juta. p.10.1-10.68.)

WOOLMAN, S. \& DE WAAL, J. 1994. Freedom of association: the right to be we. (In Van Wyk, D.H. et al., eds. Rights and constitutionalism, the new South African legal order. Cape Town: Juta. p.338-386.)

\section{Saakverwysing}

Prince v President Cape Law Society 20022 SA 794 (KH)

\section{Kernbegrippe}

Afrikaner-Christene: roeping

grondwetlike regte: gelykheid; vryheid van assosiasie

vreemdelingskap

\section{Key concepts}

Afrikaner Christians: calling

alienienation

constitutional rights: equity; freedom of association 